Original article / Оригинальная статья

DOI: https://doi.org/10.21285/2227-2925-2020-10-3-470-478

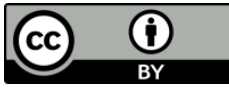

\title{
Determination of phenolic compounds in water-ethanol extracts of Populus tremula L. leaves using high-performance liquid chromatography
}

\author{
(c) Olga V. Kotsupiy*, Yulia V. Zagurskaya**, Vladimir I. Ufimtsev** \\ ${ }^{*}$ Central Siberian Botanical Garden SB RAS, Novosibirsk, Russian Federation \\ ${ }^{* *}$ Federal Research Center of Coal and Coal Chemistry SB RAS \\ (Institute of Human Ecology), Kemerovo, Russian Federation
}

\begin{abstract}
The analytical task of determining the phenolic compound content of water-ethanol extracts of Populus tremula L. (common aspen) leaves is complicated by the heterogeneity of compound groups having different polarities and appearing in varying concentrations. The purpose of the present work is to study the conditions of solid-phase extraction and high-performance liquid chromatography used to analyse the content of different groups of phenolic compounds in water-ethanol extracts of leaves from the P. tremula plant. In order to facilitate the derivation of phenolic compounds, an exhaustive extraction process was carried out using ethanol. Solid-phase extraction was carried out using a Diapak C16 cartridge, after which the eluates were passed through a membrane filter having a pore diameter of $0.45 \mu \mathrm{m}$. The high-performance liquid chromatography method was used to determine the content of phenolic acids and flavonoid glycosides, as well as salicin and individual flavonoid glycoside components: hyperoside, rutin, astragalin and two unidentified flavonoid glycosides in aqueous (analyte 1) and aqueous-alcoholic fractions (analyte 2) in two systems along the gradient elution. The requirement of analysing the primary aqueous eluate together or in parallel with the main aqueous-alcoholic fraction in the preparation of $P$. tremula leaf extracts for high-performance liquid chromatography using solid-phase extraction cartridges was substantiated. For separating the extract to determine the hydroxycinnamic and hydroxybenzoic acid content, it is preferable to use system 2; for determining the phenologlycoside (salicin) content, system 1 is more effective. Flavonoid glycosides (hyperoside, rutin, astragalin and two unidentified flavonoids) make the most significant contribution to the difference between the aqueous and aqueous-alcoholic fractions.
\end{abstract}

Keywords: phenolic compounds, Populus tremula, solid-phase extraction, high-performance liquid chromatography (HPLC), sample preparation

Acknowledgments: The work was carried out within the framework of the projects of Central Siberian Botanic Garden SB RAS no. AAAA-A17-117012610051-5 and Federal Research Center of Coal and Coal Chemistry SB RAS no. AAAA-A17-117041410053-1.

Information about the article: Received March 13, 2020; accepted for publication August 31, 2020; available online September 30. 2020.

For citation: Kotsupiy OV, Zagurskaya YuV, Ufimtsev VI. Determination of phenolic compounds in waterethanol extracts of Populus tremula L. leaves using high-performance liquid chromatography. Izvestiya Vuzov. Prikladnaya Khimiya $i$ Biotekhnologiya $=$ Proceedings of Universities. Applied Chemistry and Biotechnology. 2020;10(3):470-478. (In English) https://doi.org/10.21285/2227-2925-2020-10-3-470-478

УДК $581.19: 581.5(582.623 .2)$

\section{Определение фенольных соединений в водно-этанольных экстрактах листьев Populus tremula L. с помощью высокоэффективной жидкостной хроматографии}

\author{
О.В. Коцупий \\ *Центральный сибирский ботанический сад СО РАН, \\ г. Новосибирск, Российская Федерация \\ **Федеральный исследовательский центр угля и углехимии СО РАН (Институт экологии человека), \\ г. Кемерово, Российская Федерация
}

Резюме: Водно-этанольный экстракт листьев Populus tremula L. (осина обыкновенная) включает различные группы фенольных соединений с разной полярностью и различной концентрацией веществ, что осложняет аналитическую задачу при определении их содержания. Цель работы - 
изучить условия твердофазной экстракции и высокоэффрективной жидкостной хроматографии при исследовании содержания разных групп фенольных соединений в водно-этанольных экстракmax листьев P. tremula. Для извлечения френольных соединений проводили исчерпывающую экстракцию этанолом. Твердофазную экстракцию осуществляли с помощью патрона Диапак С16, после чего элюаты пропускали через мембранный фрильтр с диаметром пор 0,45 мкм. Методом высокоэффрективной жидкостной хроматографиии определяли содержание френолокислот и гликозидов фрлавоноидов, а также салицина и индивидуальных компонентов гликозидов фрлавоноидов: гиперозида, рутина, астрагалина и двух неиндентифицированных гликозидов фрлавоноидов в водной (аналит 1) и водно-спиртовой фрракциях (аналит 2) в двух системах, различающихся по градиенту элюирования. Доказана необходимость анализа первичного водного элюата совместно или параллельно с основной водно-спиртовой фрракцией при подготовке экстрактов листьев P. tremula для высокоэфрфективной жидкостной хроматографии с помощью картриджей твердофразной экстракции. Для разделения экстракта с целью определения содержания компонентов гидроксикоричных и гидроксибензойных кислот предпочтительнее использовать систему 2, для определения содержания френологликозидов (салицина) - систему 1. Гликозиды фрлавоноидов (гиперозид, рутин, астрагалин и два неидентифицированных фрлавоноида) вносят наиболее весомый вклад в различие двух фрракций - водной и водно-спиртовой.

Ключевые слова: френольные соединения, Populus tremula, твердофразная экстракция, высокоэффрективная жидкостная хроматография, пробоподготовка

Благодарность: Работа выполнена в рамках проектов Центрального сибирского ботанического сада СО РАН № АAАA-А17-117012610051-5 и Федерального исследовательского центра угля и углехимии СО РАН № АAАA-A17-117041410053-1.

Информация о статье: Дата поступления 13 марта 2020 е.; дата принятия к печати 31 августа 2020 г.; дата онлайн-размещения 30 сентября 2020 2.

Для цитирования: Коцупий О.В., Загурская Ю.В., Уфимцев В.И. Определение фенольных соединений в водно-этанольных экстрактах листьев Populus tremula L. с помощью высокоэффективной жидкостной хроматографии. Известия вузов. Прикладная химия и биотехнология. 2020. Т. 10. N 3. C. 470-478. https://doi.org/10.21285/2227-2925-2020-10-3-470-478

\section{INTRODUCTION}

The study of phenolic compounds (PCs) in plant material is of current interest in order to identify new economically-significant sources of biologicallyactive substances, primarily for medicinal use. PCs are also widely used as chemotaxonomic markers, as well as, more recently, within the framework of ecological research in the selection of bioindication objects and methods for determining environmental wellbeing. Moreover, for taxonomic and bioindication purposes, it is necessary to obtain the most complete information on the content of individual phenolic substances, which presupposes exhaustive extraction and careful sample preparation. However, the complex matrix composition inherent in crude plant extracts complicates the analytical problem, negatively impacting on analysis results [1]. In terms of significantly simplifying the analysis procedure and improving its metrological characteristics, the most efficient and versatile method for isolation, purification and concentration of phenolic substances from plant samples having a complex composition is solid-phase extraction (SPE) [2, 3].

An analysis of publications indexed in the Web of Science citation database (@ Clarivate) for 20132018 showed that, when performing tasks requiring maximum preservation of the extract for the subsequent study of PS, membrane filters are most typically used during preliminary sample preparation, often in conjunction with centrifugation. Mention of the use of solid-phase extraction (SPE), including the use of cartridges such as Phenomenex Strata-X and $\mathrm{C}_{18}$ (Torrance, CA, USA), Agilent SampliQ (Agilent Technologies, CA, USA) separately or together with other methods of purification and / or fractionation, was found in about a third of the reviewed publications [4-13]. In the Russian Federation, domestically-produced Diapak cartridges are successfully used (CJSC BioKhimMak ST, Moscow) for SPE purposes. For polyphenolic compounds, a sorbent with a grafted $\mathrm{C} 18$ phase is optimally used for sample preparation within the framework of HPLC analysis [1].

According to the literature data, various groups of phenolic compounds are present in the leaves of Populus tremula L. (common aspen): flavonoids (hyperoside, rutin, quercitrin, isoquercitrin, astragalin), nine phenolic glycosides, including salicin and tremulacin, as well as chlorogenic acid and esters of $p$ coumaric, ferulic and cinnamic acids [14-17]. Phenol glycosides constitute a significant proportion of PCs in aspen leaves, significantly exceeding the flavonoid and phenol carboxylic acid content [15]. The separation completeness of compounds and quantitative determination accuracy can be influenced by the chemical nature of individual components in the intact sample, as well as their number and content $[5,18]$. A matrix with the joint presence of a sufficiently large 
number of substan-ces of different polarities having different concentrations presents difficulties in performing tasks to determine component content and composition.

In our study examining the content of different groups of phenolic compounds in water-ethanol extracts of leaves of $P$. tremula, we set the goal of studying the conditions of SPE and HPLC analysis.

\section{MATERIALS AND METHODS}

We examined mature undamaged leaf blades from aspen trees of between 10 and 15 years old, collected from the 1st to the 5th August, 2015, on the territory of the Kedrovsky coal mine in southwestern Siberia. According to the results of differential spectrophotometry with $\mathrm{AlCl}_{3}$, the different total flavonoid glycoside content in terms of rutin following a single cold extraction with $95 \%$ ethanol was as follows: sample $1(\mathrm{O} 1)-0.4 \pm 0.1$; sample $2(\mathrm{O} 2)$ $-0.6 \pm 0.1$; sample $3(\mathrm{O} 3)-1.0 \pm 0.1$.

In order to extract phenolic compounds, an exact weighed portion $(0.120-0.200 \mathrm{~g})$ of the crushed air-dry material was first obtained by cold extraction with $70 \%$ ethanol in darkness for $48 \mathrm{~h}$. Next, an exhaustive extraction was carried out three times with $50 \%$ ethanol while heating in a water bath: 1) $30 \mathrm{ml}$ of the extractant - for 30 minutes; 2) $20 \mathrm{ml}$ of extractant - for 20 minutes; 3) $10 \mathrm{ml}$ of extractant - for 10 minutes. The combined extract was evaporated to dryness and brought to a volume of $3 \mathrm{ml}$ with $50 \%$ ethanol.

For SPE, $1 \mathrm{ml}$ of the extract was diluted with bidistilled water to $5 \mathrm{ml}$ and passed through a Diapak C16 concentrating cartridge (CJSC BioKhimMak ST). The substances were washed off the cartridge with a small amount $(5 \mathrm{ml})$ of solvent with an increasing concentration of ethanol (40, 70 and 96\%).

During the preparation of $P$. tremula samples, it was observed that the aqueous residue had a yellowish colour when the sample was washed through a TFE cartridge, indicating a significant content of coloured compounds, possibly of a phenolic nature. For this reason, the water residue was not discarded following sorption on the cartridge, but analysed as the first fraction (analyte $1-\mathrm{A} 1$ ) separately from the water-alcohol fraction (analyte 2 - A2). Following SPE, the eluates were passed through a membrane filter having a pore diameter of $0.45 \mu \mathrm{m}$.

The components were analysed on an Agilent 1200 liquid chromatograph fitted with a diode array detector and a ChemStation system for collecting and processing chromatographic data. The substances were separated on a Zorbax SB-C18 column having dimensions $4.6 \times 150 \mathrm{~mm}$ and a particle diameter of $5 \mu \mathrm{m}$ using a gradient elution mode. Two systems were used for the chromatographic procedure. System 1 (S1, developed for the separation of phenolic substances, primarily flavonoid glycosides): in the mobile phase, the methanol content in an aqueous solution of orthophosphoric acid $(0.1 \%)$ varied: from 32 to $33 \%$ in 27 minutes; then up to $46 \%$ - by 38 minutes; then up to $56 \%$ - by 50 minutes; and up to $100 \%$ - by 54 minutes. System 2 (S2, developed for the separation of phenolic substances, primarily phenolic acids): in the mobile phase, the methanol content in an aqueous solution of orthophosphoric acid $(0.1 \%)$ varied: from 19 to $70 \%$ - in 30 minutes; then to $100 \%$ - by $32 \mathrm{~min}$. The flow rate of the eluent is $1 \mathrm{ml} / \mathrm{min}$. Column temperature $-26{ }^{\circ} \mathrm{C}$. Volume of injected sample $-10 \mu \mathrm{l}$. Detection was carried out at analytical wavelengths $\lambda=255,270,290,340,350,360,370 \mathrm{~nm}$. To prepare the mobile phases, we used methyl alcohol (extra pure grade), orthophosphoric acid (extra pure grade) and bidistilled water. Standard solutions were prepared at a concentration of $10 \mu \mathrm{g} / \mathrm{ml}$ in ethyl alcohol. Standard samples of salicin (MP Biomedicals LLC), rutin, hyperoside and astragalin (FLUKA Analytical) were used as taps. Each variant was analysed in 4 replications.

The content of individual components $\left(C_{x}, \%\right)$ in terms of absolutely dry matter (ADM) was calculated by the formula:

$$
C_{x}=\frac{C_{c T} \times S_{1} \times V_{1} \times V_{2} \times 100}{\left.S_{2} \times M \times 10 \times 100 \quad B\right)},
$$

where $C_{s t}$ - the concentration of a standard solution of a phenolic compound (PC), $\mu \mathrm{g} / \mathrm{ml} ; S_{1}$ - the area of the PC peak in the analysed sample, a.u.; $S_{2}-$ peak area of the standard PC, a.u.; $V_{1}$ - volume of the eluate after washing out the PC from the concentrating cartridge, $\mathrm{ml} ; V_{2}$ - total extract volume, $\mathrm{ml}$; $M$ - sample weight, $\mathrm{mg}$; $B$ - raw material moisture (\%).

The salicin content was calculated in terms of salicin; phenolic acids - in terms of gallic and chlorogenic acids. The flavonoid glycoside content was calculated for quercetin using the coefficient known from the literature for converting the concentration - $2.504[19,20]$.

Statistical data processing - calculation of the average value of the feature $(M)$, its error $\left(m_{M}\right)$, variance (ANOVA, Duncan's test) and the method of principal components were carried out using the Statistica 10 application package.

\section{RESULTS AND DISCUSSION}

Hyperoside, rutin, astragalin, as well as gallic-, chlorogenic-, and cinnamic acids, were previously found in the leaves of $P$. tremula from ecotopes having varying degrees of technogenic load [21].

In this work, the composition and content of phenolic acids (PA) and flavonoids glycosides (FG) in both aqueous (A1) and aqueous-alcoholic fractions (A2) were determined in two systems differing in the elution gradient. Data on the content of differrent groups of PC are presented in Table 1. 
Table 1. Phenolic content and number of components in aqueous and aqueous-alcoholic fractions of Populus tremula leaf extracts in systems with different elution gradients (\% on ADM)

Таблица 1. Содержание фенольных соединений и число компонентов в водных и водно-спиртовых фракциях экстрактов листьев Populus tremula в системах с разным градиентом элюирования (\% на АСВ)

\begin{tabular}{|c|c|c|c|c|c|c|c|}
\hline \multirow{2}{*}{ Sample } & \multirow{2}{*}{ PC } & \multicolumn{2}{|c|}{ System 1} & \multicolumn{4}{|c|}{ System 2} \\
\hline & & $\mathrm{A} 1$ & $\mathrm{~A} 2$ & $\mathrm{~A} 1$ & $\mathrm{~A} 2$ & extract & $R, \%$ \\
\hline \multirow[t]{2}{*}{1} & \multirow{2}{*}{$\begin{array}{l}P A, \% \\
F G, \% \\
N, \text { pcs } \\
\end{array}$} & \multirow{2}{*}{$\begin{array}{c}0.74 \pm 0.01 \\
1.27 \pm 0.10 \\
33\end{array}$} & \multirow{2}{*}{$\begin{array}{c}0.50 \pm 0.01 \\
1.95 \pm 0.17 \\
44\end{array}$} & \multirow{2}{*}{$\begin{array}{c}0.91 \pm 0.01 \\
1.69 \pm 0.15 \\
57\end{array}$} & \multirow{2}{*}{$\begin{array}{c}0.39 \pm 0.01 \\
1.73 \pm 0.15 \\
46\end{array}$} & $\begin{array}{l}2.00 \pm 0.18 \\
4.96 \pm 0.40\end{array}$ & $\begin{array}{l}65 \\
69\end{array}$ \\
\hline & & & & & & \multicolumn{2}{|c|}{56} \\
\hline \multirow{2}{*}{2} & \multirow{2}{*}{$\begin{array}{l}P A, \% \\
F G, \% \\
N, \text { pcs } \\
\end{array}$} & \multirow{2}{*}{$\begin{array}{c}0.79 \pm 0.01 \\
0.81 \pm 0.01 \\
45\end{array}$} & \multirow{2}{*}{$\begin{array}{c}0.29 \pm 0.01 \\
1.01 \pm 0.01 \\
44\end{array}$} & \multirow{2}{*}{$\begin{array}{c}0.62 \pm 0.04 \\
0.81 \pm 0.01 \\
65\end{array}$} & \multirow{2}{*}{$\begin{array}{c}0.84 \pm 0.06 \\
0.99 \pm 0.01 \\
34\end{array}$} & $\begin{array}{l}2.09 \pm 0.18 \\
2.80 \pm 0.21\end{array}$ & $\begin{array}{l}67 \\
64\end{array}$ \\
\hline & & & & & & & \\
\hline \multirow{2}{*}{3} & \multirow{2}{*}{$\begin{array}{l}P A, \% \\
F G, \% \\
N, \text { pcs }\end{array}$} & \multirow{2}{*}{$\begin{array}{c}1.94 \pm 0.15 \\
1.96 \pm 0.17 \\
27\end{array}$} & \multirow{2}{*}{$\begin{array}{c}0.49 \pm 0.01 \\
1.37 \pm 0.10 \\
33\end{array}$} & \multirow{2}{*}{$\begin{array}{c}2.58 \pm 0.20 \\
2.20 \pm 0.17 \\
43\end{array}$} & \multirow{2}{*}{$\begin{array}{c}0.57 \pm 0.01 \\
1.48 \pm 0.10 \\
37\end{array}$} & $\begin{array}{l}3.51 \pm 0.25 \\
3.50 \pm 0.30\end{array}$ & $\begin{array}{c}91 \\
105\end{array}$ \\
\hline & & & & & & \multicolumn{2}{|c|}{55} \\
\hline
\end{tabular}

Note. $\mathrm{N}$ is the number of phenolic components; $\mathrm{R}$ is the degree of analyte recovery.

Earlier, possible losses of gallic and caffeic acids in the process of sample preparation of plant extracts using SPE were reported [1, 22]. In all investigated $P$. tremula samples, the aqueous eluate (A1) contains a significant amount of PA - in most cases, exceeding that of the aqueous-alcoholic analytes (see Table 1). In addition, the presence of significant amounts of phenolic - including flavonoid components was observed in the aqueous fractions of all samples (Fig. 1). Thus, in the first two samples, the FG content in the aqueous analyte is comparable to - or only 1.3-1.5 times less than - the FG content in the target aqueous-alcoholic analyte. In O3, however, the FG content in the aqueous analyte exceeds that observed in the aqueous-alcoholic analyte by 1.4-1.5 times. The lowest number of compounds for all studied variants of determination was noted for $\mathrm{O} 3$, in which the highest content of both PC groups is observed.

It is known that substances having different polarities are concentrated and desorbed from the sorbent of the cartridge to varying degrees of extraction. The recovery factor was analysed in the sys- tem having the highest total PC content and number of components, i.e. S2 (see Table 1). In an earlier work, it was indicated that the degree of extraction of rutin from an aqueous decoction of St. John's wort was $49 \%$ [1]. In our samples, the degree of extraction from the combined fractions (aqueous and aqueous-alcoholic) was for different samples: for $F G-64-105 \%$; for PA - 65-91\%. The different recovery rates are possibly related to intermolecular effects in the complex natural matrix of the aspen leaf extract, as well as to the different number and content of the determined components in the samples.

To elucidate the relationship between the PC composition and content of the aspen leaf extract with the sample preparation and HPLC analysis conditions, we determined the content of some individual substances (salicin, hyperoside, rutin and astragalin), as well as two unidentified substances (FG1 and FG2), classified as glycosides of flavonoids, according to spectral data $\left(\lambda_{\max }=255\right.$, $355 \mathrm{~nm}$ ) (Table 2).

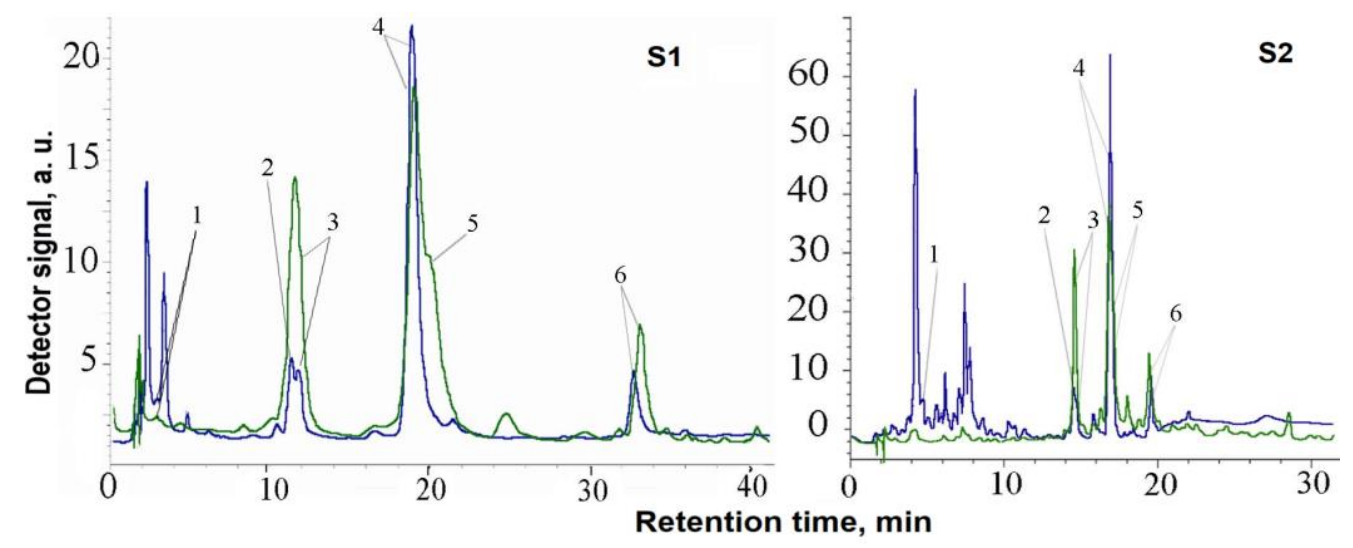

Fig. 1. HPLC chromatograms of water-ethanol extracts of Populus tremula leaves: $\mathrm{S} 1-360 \mathrm{~nm}$; $\mathrm{S} 2-325 \mathrm{~nm}$; blue line - A1, green line - A2; main components: 1 - salicin; 2 and 3 - flavonoid glycosides FG1 and FG2; 4 - hyperoside; 5 - rutin, 6 - astragalin

Рис. 1. ВЭЖХ-хроматограммы водно-этанольных экстрактов листьев Populus tremula: $\mathrm{C} 1-360$ нм, С2 - 325 нм; синяя линия - A1, зеленая линия - А2; основные компоненты: 1 - салицин, 2 и 3 - гликозиды флавоноидов ГФ1 и ГФ2, 4 - гиперозид, 5 - рутин, 6 - астрагалин 
The highest salicin content (best recovery and separation) was noted in aqueous eluates, especially during chromatography in S1. Two glycosides FG1 and FG2, which were close in retention times, were not separated in the aqueous-alcoholic eluate of either system. For O3, a different ratio of the main flavonoid components - rutin (prevailing) and hyperoside - was established than in other studied samples, in which the content of hyperoside exceeded the amount of rutin by 2 or more times (see Table 1).

To identify the most significant influencing factors from the existing number of explanatory variables (the content of analysed individual substances and their sums), the principal component analysis (PCA) method was applied.
We took 9 signs: content salicin, hyperoside, rutin, astragalin, flavonoid glycosides FG1 and FG2, the sum of five glycosides, the sum of $F G$ and the sum of FC. The data visualisation is graphically presented in the scatterplot (Fig. 2).

For the PC of aspen leaves, sufficiently clear scattering regions can be observed on a threedimensional diagram constructed using the first three factors (F1-F2-F3). The compact area of dispersion of indicators of the PC content in the $\mathrm{O} 2$ aspen leaves is separated from others by the first factor. The most significant correlation coefficients noted for the first factor are the sum of FG, the sum of five glycosides and the sum of PC, as well as the salicin and rutin content. Different samples have

Table 2. Content of individual components of phenolic compounds in aqueous and aqueous-alcoholic fractions of Populus tremula leaf extracts in systems with different elution gradients (\% on ADM)

Таблица 2. Содержание индивидуальных компонентов фенольных соединений в водных и водно-спиртовых фракциях экстрактов листьев Populus tremula в системах с разным градиентом элюирования (\% на ACB)

\begin{tabular}{|c|c|c|c|c|c|c|c|}
\hline $\begin{array}{l}\text { Sample / } \\
\text { analyte / } \\
\text { system }\end{array}$ & Salicin & FG1 & FG2 & Hyperoside & Rutin & Astragalin & $\begin{array}{c}\text { Total } \\
\text { amount } \\
\text { of FG }\end{array}$ \\
\hline $\begin{array}{l}\text { O1/A1/C1 } \\
\text { O1/A2/C1 } \\
\text { O1/A1/C2 } \\
\text { O1/A2/C2 }\end{array}$ & $\begin{array}{c}0.78 \pm 0.06^{b c} \\
0.21 \pm 0.02^{d} \\
0.67 \pm 0.05^{c} \\
n / d\end{array}$ & $\begin{array}{c}0.075 \pm 0.006^{b} \\
n / d \\
0.100 \pm 0.009^{a} \\
n / d\end{array}$ & $\begin{array}{l}0.075 \pm 0.006^{f} \\
0.575 \pm 0.030^{a} \\
0.075 \pm 0.006^{f} \\
0.275 \pm 0.023^{d}\end{array}$ & $\begin{array}{c}0.925 \pm 0.030^{\mathrm{a}} \\
0.825 \pm 0.030^{\mathrm{b}} \\
0.85 \pm 0.06^{\mathrm{b}} \\
0.325 \pm 0.025^{\mathrm{cf}}\end{array}$ & $\begin{array}{c}n / d \\
0.43 \pm 0.03^{c} \\
0.175 \pm 0.015^{f} \\
0.30 \pm 0.02^{d}\end{array}$ & $\begin{array}{l}0.18 \pm 0.01^{c} \\
0.25 \pm 0.02^{a} \\
0.15 \pm 0.01^{d} \\
0.23 \pm 0.02^{b}\end{array}$ & $\begin{array}{l}1.25 \pm 0.10^{d} \\
1.65 \pm 0.15^{b} \\
1.35 \pm 0.10^{d c} \\
1.13 \pm 0.10^{a}\end{array}$ \\
\hline $\begin{array}{l}\text { O2/A1/C1 } \\
\text { O2/A2/C1 } \\
\text { O2/A1/C2 } \\
\text { O2/A2/C2 }\end{array}$ & $\begin{array}{c}0.84 \pm 0.07^{b} \\
0.15 \pm 0.01^{d} \\
0.24 \pm 0.02^{d} \\
n / d\end{array}$ & $\begin{array}{c}0.050 \pm 0.003^{c} \\
n / d \\
0.050 \pm 0.003^{c} \\
n / d^{a}\end{array}$ & $\begin{array}{l}0.075 \pm 0.006^{f} \\
0.175 \pm 0.013^{c} \\
0.075 \pm 0.006^{f} \\
0.225 \pm 0.017^{e}\end{array}$ & $\begin{array}{c}0.275 \pm 0.020^{\mathrm{fg}} \\
0.20 \pm 0.01^{\mathrm{d}} \\
0.30 \pm 0.02^{\mathrm{fg}} \\
0.375 \pm 0.030^{\mathrm{c}}\end{array}$ & $\begin{array}{c}0.075 \pm 0.006^{h} \\
0.175 \pm 0.015^{f} \\
0.075 \pm 0.006^{h} \\
0.050 \pm 0.003^{g h}\end{array}$ & $\begin{array}{c}0.100 \pm 0.009^{\mathrm{e}} \\
0.13 \pm 0.01^{\mathrm{g}} \\
0.13 \pm 0.01^{\mathrm{g}} \\
0.075 \pm 0.006^{f}\end{array}$ & $\begin{array}{l}0.58 \pm 0.04^{f} \\
0.68 \pm 0.05^{f} \\
0.63 \pm 0.05^{f} \\
0.73 \pm 0.06^{f}\end{array}$ \\
\hline $\begin{array}{l}\text { O3/A1/C1 } \\
\text { O3/A2/C1 } \\
\text { O3/A1/C2 } \\
\text { O3/A2/C2 }\end{array}$ & $\begin{array}{c}1.73 \pm 0.15^{a} \\
0.16 \pm 0.01^{d} \\
0.69 \pm 0.05^{c} \\
n / d\end{array}$ & $\begin{array}{c}0.055 \pm 0.003^{c} \\
n / d \\
0.07 \pm 0.006^{b} \\
n / d\end{array}$ & $\begin{array}{c}0.33 \pm 0.02^{b} \\
0.107 \pm 0.009^{f} \\
0.25 \pm 0.02^{d e} \\
0.110 \pm 0.009^{f}\end{array}$ & $\begin{array}{c}0.303 \pm 0.020^{\mathrm{fg}} \\
0.055 \pm 0.003^{\mathrm{e}} \\
0.25 \pm 0.02^{\mathrm{dg}} \\
0.045 \pm 0.003^{\mathrm{e}}\end{array}$ & $\begin{array}{l}0.89 \pm 0.06^{\mathrm{a}} \\
0.72 \pm 0.05^{\mathrm{e}} \\
0.77 \pm 0.05^{\mathrm{e}} \\
0.65 \pm 0.05^{\mathrm{b}}\end{array}$ & $\begin{array}{c}0.11 \pm 0.09^{g} \\
0.090 \pm 0.008^{e} \\
0.06 \pm 0.004^{f} \\
0.16 \pm 0.01^{d}\end{array}$ & $\begin{array}{l}1.70 \pm 0.15^{b} \\
0.95 \pm 0.15^{\mathrm{e}} \\
1.40 \pm 0.10^{\mathrm{d}} \\
0.95 \pm 0.09^{\mathrm{e}}\end{array}$ \\
\hline
\end{tabular}

Note. $n / d$ - not detected; column averages followed by like letters do not differ significantly from each other according to Duncan's test at $P=0.05$.
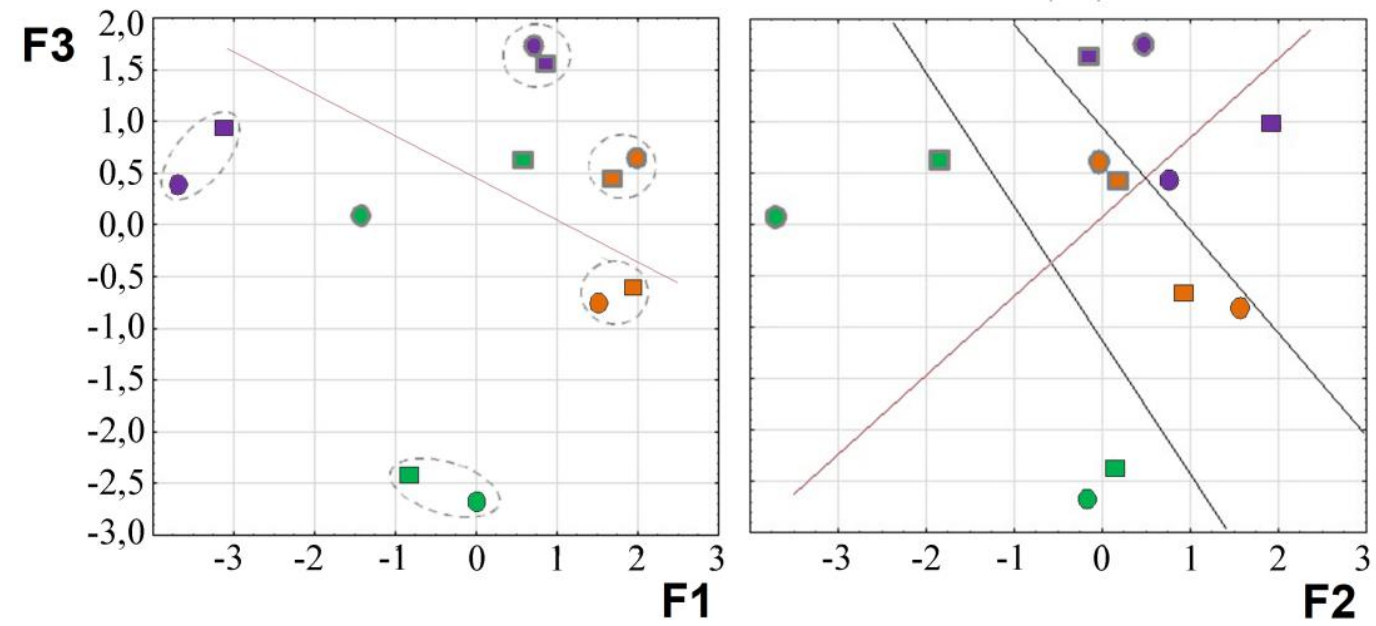

Fig. 2. Application of the PCA method in the distribution of water- and aqueous-alcoholic fractions of Populus tremula leaf extracts: green - O1, orange - O2, violet - O3; circle - S1, square -S2; thin black border line $-\mathrm{A} 1$; bold grey - A2

Рис. 2. Применение метода главных компонент при распределении водных и водно-спиртовых фрракций экстрактов листьев Populus tremula: зеленый - О1, оранжевый - О2, фиолетовый - О3; круг - C1, квадрат - С2; линия границы тонкая черная - A1, жирная серая - A2 
their own scattering regions according to F2-F3 (separated by black lines in the figure). In addition, according to $\mathrm{F} 2-\mathrm{F} 3$, there are two scattering regions, represented by (1) aqueous and (2) aqueousalcoholic fractions, although some points are located nearby. The second factor correlates most strongly with the astragalin and FG2 content, while the third correlates most strongly with the hyperoside, FG1 and rutin content. According to F1-F3, the region with aqueous-alcoholic eluates is also localised, except for $\mathrm{O} 1$ in the aqueous-alcoholic fraction $\mathrm{S} 1$.

Thus, the differences between the aqueous and aqueous-alcoholic fractions, as well as the differences of the samples from each other, is mainly due to the content of individual flavonoid components: hyperoside, astragalin, rutin, FG1 and FG2. Differences in the PC content of aspen leaves largely depend on the analysed fraction (aqueous or aqueous-alcoholic) (see Fig. 2). The salicin and PC content correlates with the sample preparation conditions and elution gradient in HPLC analysis. Salicin is best detected in the S1 aqueous eluate (see Table 2). S2 is preferable for use at a sufficiently high content of PA in the test material, in particular, for the analysis of the aqueous fraction of $P$. tremula leaf extracts (see Table 1).

\section{CONCLUSIONS}

1. In order to study the PC composition and content by means of HPLC when preparing Populus tremula extracts using SPE cartridges, it is necessary to analyse the aqueous eluate together or in parallel with the main aqueous-alcoholic fraction.

2. In order to separate the extract for determining the hydroxycinnamic and hydroxybenzoic acid content, it is preferable to use system 2; for determining the phenologlycoside (salicin) content, system 1 is more effective.

3. Preferred conditions for sample preparation and HPLC analysis for optimal separation of the component composition of flavonoid glycosides have not been identified. The content of individual flavonoids (hyperoside, astragalin, rutin, and two unidentified flavonoids) makes the most significant contribution to the differences between aqueous and aqueous-alcoholic fractions.

\section{REFERENCES}

1. Temerdashev ZA, Milevskaya VV, Kiseleva NV, Vernikovskaya NA, Korobkov VA. Sorptionchromatographic determination of gallic, caffeic acids, rutin and (-)-epicatechin in herbs. Analitika $i$ control = Analytics and Control. 2013;2:211-218. (In Russian)

2. Saprykin LV, Saprykina LV. Methodology of analytical application of solid-phase extraction. Sorbtsionnye $i$ khromatograficheskie protsessy. 2007;7(3):397-409. (In Russian)

3. Kudrinskaya VA, Dmitrienko SG, Zolotov YuA. Synthesis and study of sorption properties of molecularly imprinted polymers for quercetin. Moscow University Chemistry Bulletin. 2009;64(3):124129. https://doi.org/10.3103/S0027131409030031

4. Zanutto FV, Boldrin PK, Varanda EA, Fernandes de Souza S, Sano PT, Vilegas W, et al. Characterization of flavonoids and naphthopyranones in methanol extracts of Paepalanthus chiquitensis Herzog HPLC-ESI-IT-MSn and their mutagenic activity. Molecules. 2012;18(1):244-262. https://doi.org/10.3390/molecules 18010244

5. Simirgiotis MJ, Schmeda-Hirschmann G, Bórquez J, Kennelly EJ. The Passiflora tripartita (Banana Passion) fruit: a source of bioactive flavonoid $C$-glycosides isolated by HSCCC and characterized by HPLC-DAD-ESI/MS/MS. Molecules. 2013;18(2):1672-1692. https://doi.org/10.3390/molecules 18021672

6. Asghari A, Barfi B, Barfi A, Saeidi I, Ghollasi Moud F, Peyrovi M, et al. Comparison between conventional solid phase extraction and its simplified method for HPLC determination of five flavonoids in orange, tangerine, and lime juice samples. Acta Chromatographica. 2014;26(1):157-175. https://doi. org/10.1556/AChrom.26.2014.1.12
7. Costa DLMG, Rinaldo D, Varanda EA, de Sousa JF, Nasser ALM, Silva ACZ, et al. Flavonoid detection in hydroethanolic extract of Pouteria torta (Sapotaceae) Leaves by HPLC-DAD and the determination of Its mutagenic activity. Journal of Medicinal Food. 2014;17(10):1103-1112. https://doi.org/ 10.1089/jmf.2013.0116

8. Mehta JP, Fultariya $\mathrm{CR}$, Parmar $\mathrm{PH}$, Vadia $\mathrm{SH}$, Golakiya BA. Determination of phenolic acids and a flavonoid in Eleusine coracana (L.) by semipreparative HPLC photo diode array detector. Journal of Analytical Chemistry. 2015;70(3):369-373. https://doi.org/10.1134/S1061934815030090

9. Hsu BY, Lin SW, Stephen Inbaraj B, Chen $\mathrm{BH}$. Simultaneous determination of phenolic acids and flavonoids in Chenopodium formosanum Koidz. (djulis) by HPLC-DAD-ESI-MS/MS. Journal of Pharmaceutical and Biomedical Analysis. 2017; 132:109-116. https://doi.org/10.1016/j.jpba.2016.09. 027

10. Gomes SVF, Portugal LA, dos Anjos JP, de Jesus ON, de Oliveira EJ, David JP, Davida JM. Accelerated solvent extraction of phenolic compounds exploiting a Box-Behnken design and quantification of five flavonoids by HPLC-DAD in Passiflora species. Microchemical Journal. 2017;132:2835. https://doi.org/10.1016/j.microc.2016.12.021

11. Tewari R, Gupta M, Ahmad F, Rout PK, Misra $L$, Patwardhan $A$, et al. Extraction, quantification and antioxidant activities of flavonoids, polyphenols and pinitol from wild and cultivated Saraca asoca bark using RP-HPLC-PDA-RI method. Industrial Crops and Products. 2017;103:73-80. https://doi. org/10.1016/j.indcrop.2017.03.036

12. Ciric $A$, Jelikic-Stankov $M$, Cvijovic $M$, Djurdjevic P. Statistical optimization of an RP-HPLC 
method for the determination of selected flavonoids in berry juices and evaluation of their antioxidant activities. Biomedical Chromatography. 2018;32(4). Art. no. e4150. https://doi.org/10.1002/bmc.4150

13. Kuppusamy $P$, Lee KD, Song $C E$, llavenil $S$, Srigopalram S, Arasu MV, et al. Quantification of major phenolic and flavonoid markers in forage crop Lolium multiflorum using HPLC-DAD. Revista Brasileira de Farmacognosia. 2018;28(3):282-288. https://doi.org/10.1016/j.bjp.2018.03.006

14. Häikiö $E$, Makkonen $M$, Julkunen-Tiitto $R$, Sitte J, Freiwald V, Silfver T, et al. Performance and secondary chemistry of two hybrid Aspen (Populus tremula L. $x$ Populus tremuloides Michx.) clones in long-term elevated ozone ex-posure. Journal of Chemical Ecology. 2009;35(6):664-678. https://doi. org/10.1007/s10886-009-9644-2

15. Lobanova IYu. Phenolic compounds of leaves of Populus tremula L. as the basis for creation of preparation of anti-inflammatory action. Vestnik ural'skoi meditsinskoi akademicheskoi nauki. 2011;3/1:67-68. (In Russian)

16. Lobanova IYu, Turetskova VF. Isolation and study of the composition of flavonoids of aspen leaves. Khimija rastitel'nogo syr'ja = Chemistry of plant raw material. 2011;2:117-122. (In Russian)

17. Banayev YeV, Shishkin SV, Voronkova MS, Belanova AP, Tomoshevich MA. Morphological and biochemical features of Populus $\times$ canescens in natural populations of the Altai region. Vestnik Altaiskogo gosudarstvennogo agrarnogo universiteta = Bulletin of Altai State Agricultural University. 2017; 8:90-97. (In Russian)

18. Sychev KS, Davankov VA. Materials and methods for sample preparation in chromatography: solid-phase concentration and adsorption purification. Sorbtsionnye i khromatograficheskie protsessy. 2004;4(1):5-28. (In Russian)

19. Van Beek TA. Chemical analysis of Ginkgo biloba leaves and extracts. Journal of Chromatograhpy. A. 2002;967(1):21-55. https://doi.org/10.1016/ S0021-9673(02)00172-3

20. Yur'ev DV., Ehller KI, Arzamascev AP. Analysis flavonolglycosides in preparations and dietary supplements based on Ginkgo biloba extract. Farmatsiya = Pharmacy. 2003;2:7-9. (In Russian)

21. Zagurskaya YuV, Siromlya TI, Kotsupiy OV, Babaeva EYu, Ufimtsev VI._Physiological and biochemical characteristics of $\bar{P}$ opulus tremula leaves in anthropogenic disturbed habitats. BIO Web of Conferences. 2018;11. Art. no. 00050. 4 p. https://doi.org/10.1051/bioconf/20181100050

22. Shkarina El, Maksimova TV, Nikulina IN, Lozovskaya EL, Chumakova ZV, Pakhomov VP, et al. Effect of biologically active substances on the antioxidant activity of phytopreparations. Pharmaceutical Chemistry Journal. 2001;35(6):333-340. https://doi.org/10.1023/A:1012349806071

\section{БИБЛИОГРАФИЧЕСКИЙ СПИСОК}

1. Темердашев 3.А., Милевская В.В., Киселева Н.В., Верниковская Н.А., Коробков В.А. Сорбционно-хроматографическое определение галловой, кофейной кислот, рутина и эпикатехина в лекарственных растениях // Аналитика и контроль. 2013. Т. 17. N 2. С. 211-218.

2. Сапрыкин Л.В., Сапрыкина Л.В. Методология аналитического применения твердофазной экстракции // Сорбционные и хроматографические процессы. 2007. Т. 7. Вып. 3. С. 397-409.

3. Kudrinskaya V.A., Dmitrienko S.G., Zolotov Yu.A. Synthesis and study of sorption properties of molecularly imprinted polymers for quercetin // Moscow University Chemistry Bulletin. 2009. Vol. 64. Issue 3. P. 124-129. https://doi.org/10.3103/S0027 131409030031

4. Zanutto F.V., Boldrin P.K., Varanda E.A., Fernandes de Souza S., Sano P.T., Vilegas W., et al. Characterization of flavonoids and naphthopyranones in methanol extracts of Paepalanthus chiquitensis Herzog HPLC-ESI-IT-MSn and their mutagenic activity // Molecules. 2012. Vol. 18. Issue 1. P. 244-262. https://doi.org/10.3390/molecules 180 10244

5. Simirgiotis M.J., Schmeda-Hirschmann G., Bórquez J., Kennelly E.J. The Passiflora tripartita (Banana Passion) fruit: a source of bioactive flavonoid $C$-glycosides isolated by HSCCC and characterized by HPLC-DAD-ESI/MS/MS // Molecules.
2013. Vol. 18. Issue 2. P. 1672-1692. https://doi.org/10.3390/molecules18021672

6. Asghari A., Barfi B., Barfi A., Saeidi I., Ghollasi Moud F., Peyrovi M., et al. Comparison between conventional solid phase extraction and its simplified method for HPLC determination of five flavonoids in orange, tangerine, and lime juice samples // Acta Chromatographica. 2014. Vol. 26. Issue 1. P. 157-175. https://doi.org/10.1556/AChrom.26.2 014.1 .12

7. Costa D.L.M.G., Rinaldo D., Varanda E.A., de Sousa J.F., Nasser A.L.M., Silva A.C.Z., et al. Flavonoid detection in hydroethanolic extract of Pouteria torta (Sapotaceae) Leaves by HPLC-DAD and the determination of Its mutagenic activity // Journal of Medicinal Food. 2014. Vol. 17. Issue 10. P. 11031112. https://doi.org/10.1089/jmf.2013.0116

8. Mehta J.P., Fultariya C.R., Parmar P.H., Vadia S.H., Golakiya B.A. Determination of phenolic acids and a flavonoid in Eleusine coracana (L.) by semi-preparative HPLC photo diode array detector // Journal of Analytical Chemistry. 2015. Vol. 70, Issue 3. P. 369-373. https://doi.org/10.1134/S1061934815 030090

9. Hsu B.Y., Lin S.W., Stephen Inbaraj B., Chen B.H. Simultaneous determination of phenolic acids and flavonoids in Chenopodium formosanum Koidz. (djulis) by HPLC-DAD-ESI-MS/MS // Journal of Pharmaceutical and Biomedical Analysis. 2017. Vol. 
132. P. 109-116. https://doi.org/10.1016/j.jpba.201 6.09.027

10. Gomes S.V.F., Portugal L.A., dos Anjos J.P., de Jesus O.N., de Oliveira E.J., David J.P., Davida J.M. Accelerated solvent extraction of phenolic compounds exploiting a Box-Behnken design and quantification of five flavonoids by HPLC-DAD in Passiflora species // Microchemical Journal. 2017. Vol. 132. P. 28-35. https://doi.org/10.1016/j.microc. 2016.12.021

11. Tewari R., Gupta M., Ahmad F., Rout P.K., Misra L., Patwardhan A., et al. Extraction, quantification and antioxidant activities of flavonoids, polyphenols and pinitol from wild and cultivated Saraca asoca bark using RP-HPLC-PDA-RI method // Industrial Crops and Products. 2017. Vol. 103. P. 7380. https://doi.org/10.1016/j.indcrop.2017.03.036

12. Ciric A., Jelikic-Stankov M., Cvijovic M., Djurdjevic P. Statistical optimization of an RP-HPLC method for the determination of selected flavonoids in berry juices and evaluation of their antioxidant activities // Biomedical Chromatography. 2018. Vol. 32. Issue 4. Art. no. e4150. https://doi.org/10.1002/ bmc. 4150

13. Kuppusamy P., Lee K.D., Song C.E., Ilavenil S., Srigopalram S., Arasu M.V., et al. Quantification of major phenolic and flavonoid markers in forage crop Lolium multiflorum using HPLC-DAD // Revista Brasileira de Farmacognosia. 2018. Vol. 28. Issue 3. P. 282-288. https://doi.org/10.1016/j.bjp.2018.03. 006

14. Häikiö E., Makkonen M., Julkunen-Tiitto R., Sitte J., Freiwald V., Silfver T., et al. Performance and secondary chemistry of two hybrid Aspen (Populus tremula L. x Populus tremuloides Michx.) clones in long-term elevated ozone ex-posure // Journal of Chemical Ecology. 2009. Vol. 35. Issue 6. P. 664-678. https://doi.org/10.1007/s10886-009-96 44-2

15. Лобанова И.Ю. Фенольные соединения листьев осины обыкновенной как основа создания препарата противовоспалительного действия // Вестник уральской медицинской академической науки. 2011. N 3/1. С. 67-68.

16. Лобанова И.Ю., Турецкова В.Ф. Выделение и изучение состава фллавоноидов листьев осины обыкновенной // Химия растительного сырья. 2011. N 2. С. 117-122.

17. Банаев Е.В., Шишкин С.В., Воронкова М.С., Беланова А.П., Томошевич М.А. Морфологические и биохимические особенности Populus $\times$ canescens в природных популяциях Алтайского Края // Вестник Алтайского государственного аграрного университета. 2017. N 8 (154). С. 90-97.

18. Сычев К.С., Даванков В.А. Материалы и методы пробоподготовки в хроматографии: твердофразное концентрирование и адсорбционная очистка // Сорбционные и хроматографические процессы. 2004. Т. 4. Вып.1. С. 5-28.

19. Van Beek T.A. Chemical analysis of Ginkgo biloba leaves and extracts // Journal of Chromatograhpy. A. 2002. Vol. 967. Issue 1. P. 21-55. https://doi.org/10.1016/S0021-9673(02)00172-3

20. Юрьев Д.В., Эллер К.И., Арзамасцев А.П. Анализ фллавонолгликозидов в препаратах и БАД на основе экстракта Ginkgo biloba // Фармация. 2003. N 2. C. 7-9.

21. Zagurskaya Yu.V., Siromlya T.I., Kotsupiy O.V., Babaeva E.Yu., Ufimtsev V.I. Physiological and biochemical characteristics of Populus tremula leaves in anthropogenic disturbed habitats // BIO Web of Conferences. 2018. Vol. 11. Art. no. 00050. 4 p. https://doi.org/10.1051/bioconf/20181100050

22. Shkarina E.I., Maksimova T.V., Nikulina I.N., Lozovskaya E.L., Chumakova Z.V., Pakhomov V.P., et al. Effect of biologically active substances on the antioxidant activity of phytopreparations // Pharmaceutical Chemistry Journal. 2001. Vol. 35. Issue 6. P. 333-340. https://doi.org/10.1023/A:1012349806 071

\section{Критерии авторства}

Коцупий О.В., Загурская Ю.В., Уфимцев В.И. выполнили экспериментальную работу. Авторы совместно обобщили результаты, написали рукопись, имеют на статью равные авторские права и несут равную ответственность за плагиат.

\section{Конфликт интересов}

Авторы заявляют об отсутствии конфрликта интересов.

Все авторы прочитали и одобрили окончательный вариант рукописи.

The final manuscript has been read and approved by all the co-authors. 
Kotsupiy O.V., Zagurskaya Yu.V., Ufimtsev V.I. Determination of phenolic compounds .. Коцупий О.В., Загурская Ю.В., Уфимцев В.И. Определение фенольных соединений ...

Olga V. Kotsupiy,

Cand. Sci. (Biology), Researcher,

Central Siberian Botanical Garden SB RAS,

101, Zolotodolinskaya St.,

Novosibirsk, 630090,

Russian Federation,

凶e-mail: olnevaster@gmail.com

\section{Yulia V. Zagurskaya,}

Cand. Sci. (Biology), Researcher, Federal Research Center of Coal and Coal Chemistry SB RAS

(Institute of Human Ecology),

18, Sovetskii Ave., Kemerovo, 650000,

Russian Federation,

e-mail: syjil@mail.ru

\section{Vladimir I. Ufimtsev,}

Cand. Sci. (Biology), Leading Researcher,

The Federal Research Center of Coal

and Coal-Chemistry SB RAS

(Institute of Human Ecology),

18, Sovetskii Ave., Kemerovo, 650000,

Russian Federation,

e-mail: uwy2079@gmail.com

\section{Коцупий Ольга Викторовна,}

к.б.н., научный сотрудник,

Центральный Сибирский ботанический сад

CO PAH,

630090, г. Новосибирск,

ул. Золотодолинская, 101,

Российская Федерация,

\e-mail: olnevaster@gmail.com

\section{Загурская Юлия Васильевна,}

к.б.н., научный сотрудник, Федеральный исследовательский центр угля и углехимии СО РАН

(Институт экологии человека),

650000, г. Кемерово, пр-т Советский, 18, Российская Федерация,

e-mail: syjil@mail.ru

\section{Уфимцев Владимир Иванович,} к.б.н., ведущий научный сотрудник, Федеральный исследовательский центр угля и углехимии СО РАН

(Институт экологии человека),

650000, г. Кемерово, пр-т Советский, 18,

Российская Федерация,

e-mail: uwy2079@gmail.com 